УДК 930 (477): 929 Сиабченко

\title{
Віктор Савченко
}

\section{ПОАІТИЧНІ УПОДОБАННЯ ПРОФЕСОРА М. СААБЧЕНКА}

У статті розглядається еволюиія політичних поглядів профресора М. Слабченка під впливом глобальних змін (19051929 рр.). Автор закликає до дискусї̈ $і$ висловлюе припущення про те, що М. Слабченко був масоном або людиною "масонського кола", що його участь в украйнських соиіалістичних партіях, в боротьбистському підпіллі не закіниилася в 1920 роиі. Для М. Слабченка 1920-ті роки стали роками продовження політичної боротьби за украӥнську ідею й украйнську незалежність.

Ключеві слова: революиия, боротьбисти, масонство, підпілля, українізація, ДПУ.

Постать М. Є. Слабченко сприймалася сучасниками та сприймається нащадками, як образ мудрого вчителя, що все життя віддав служінню українському народу та ідеї духовного просвітництва. Аюдина гонорова та принципова, Михайло Є九исейович, сповідував принципи українського інтелігента та патриота, відстоював власні політичні погляди, яки впливали на його наукову та педагогічну діяльність.

У 1903 p. М. Слабченко вступив до української радикальної партії РУП, організувавши в Одесі їі студентську группу, став мідером студентської "Громади" в Одесі. За власними свідченнями, вже пореволюційних років, у 19051906 pp. Михайло ЄАисейович приймав участь в маніфестаціях, студентських страйках, революційних барикадних боях в Одесі. Він притримувався радикальних поглядів, стосовно необхідності соціального визволення та соціалістичних перетворень, руйнації імперії. В барикадних боях та акціях спротиву його шлях перетинався з есерами та анархістами, що стали популярні в Одесі у другий половині 1905 р. Відомо, що М. Слабченко у 1906 р. став активістом Української соціал-демократичної робітничої партії (формально був в її складі до 1918 р.). Приблизно з 1907 р. 
М. Слабченко бере участь у діяльності одеської "Просвіти", 3 1910 р. - «Одеського українського клубу" [1, с. 60-63].

В роки так званої "реакції", М. Слабченко відійшоши від радикальних ідей, вже не бере участь у підпімлі УСДРП. В цей час доля зводить його з майбутніми мідерами українських визвольних змагань, що у 1911-1913 рр. формують в Одесі таємний масонський рух: В. Чеховським (викладачем середніх навчальних закладів, майстром масонської можи «Звезда Востока", українським соціал-демократом), А. Ніковським (українським соціалістом-федералістом). Саме тоді М. Слабченко починає товарищувати з масонськими мідерамі київських масонських мож С. Єфремовим (масонська можа "Правда") та М. Василенком (керівник масонської цожи "Астрея»). 3 С. Сфремовим та А. Ніковським М. Слабченка пов'язала многорічна дружба, ідеологічна спільність, політична єдність, хоча М. Слабченко, ззовні, був значно "мівіший" за С. Єфрремова.

Можливо й сам М. Слабченко в цей час стає братоммасоном, бо його ідеологічні конструкції наближалися до ідей "поцітичного масонства". УАітку 1911 р. М. Слабченко виїхав у наукове відрядження до Франції, навчався в Школі права призького університету Сорбонна, взяв участь у заснуванні Міжнародного товариства недержавних народів - «Office nationale" в якому найбільш активно заявили про себе масони Великої Һожи "Великого Сходу Франції" [2]. Відомо, що на фронті I-ї світової війни М. Слабченко пристає до таємної військової змови (можливо, військової змови яку готували масони на поч. 1917 р. "Змова Гучкова"), котру було викрито владою. М. Слабченку загрожував розстріл, від якого його врятувала Аютнева революція. М. Слабченко не видає подробиці та детвці цієї "військової змови", вона залишаеться в його "радянський автобіографії" тільки вирваною 3 контексту згадкою. Можливо, причина "утаємничення" цієї змови в іï масонський сутності, про що необїідно було "замовчувати" за радянських часів. Навесні 1917 р. М. Слабченко стає зразком "революційного активіста" Тимчасового уряду - голова комітету офіцерської і солдатської ради, членом дивізійного комітету, організатором, керівником полкової української ради, членом ради 4-ї армії. Його кар'єрний зміт того часу нагадує числені "масонські кар'єри" 
зразка 1917 р., коли раніш невідомі офіцери або дрібні чиновники несподівано ставали "вождями революції».

Жовтневий переворот М. Слабченко вважав руйнуючим (як весь масонський загал) та скоріш за все брав участь у боротьбі за українську Одесу у січні 1918 р., коли демобілізувався з 4-ї армії, що існувала до середини січня 1918 р. Відомо, що в січні 1918 р. М. Слабченко повертається до Одеси, стає членом мівої фракції УПСР (з УСДРП він розірвав контанти, ще у 1908-1909 рр.), працює журналістом в газетах: "Известия одесского исполнительного комитета общественных организаций", "Голос ревоцюции", "Революционній вестник". На початку 1918 р. ми бачемо певні зміни в політичних переконаннях М. Слабченка, він став більш "мівим", наближаючись до позицій майбутніх боротьбистів. Статті М. Слабченка березня-квітня 1918 p. сповнені критики "з міва" на адресу Центральної Ради та М. Грушевського. У 1918 р. Михайло ЄАисейович працює журналістом в виданнях "Українське слово", "Вільне життя", "Молода Україна". Керівник одеської "Української національної Ради" А. Микалюк (мідер одеської мівої УПСР, соціалістичної одеської "Просвіти", згодом боротбистів) организовав в Одесі, під орудою В. Чеховського, школу пропагандистів - "Социалистические курсы". Ця "школа" та "Товариство ім. М. Драгоманова" при одеський гімназії iм. I. Франка, проводять пропоганду проти гетманського режиму, формують кадри дия майбутньої революції. "Украінська національна Рада" видавала в Одессе газету "Вільне життя", в якій 3 міта 1918 р. редактором стає М. Слабченко. Тоді М. Слабченко очолює одеську “Спілку вчителів", бере участь у змові з метою повалення влади гетьмана, за що гетьманська вцада запроторює М. Слабченка під арешт.

3 поваленням гетьмана прем'єр УНР В. Чеховський пропонує М. Слабченку посаду міністра юстиції в Директорії УНР, а С. Петлюра - посади в секретаріаті УСДРП. Відомо, що на весні 1919 р. С. Петлюра збирає всіх українських масонів дия того, що б створити загальну масонську "Велику Аожу України". Став головою Директорії УНР С. Петлюра надає важливі державні посади масонам: В. Покоповичу, А. Аевицькому, А. Ніковському та ін. Існує інформація, що

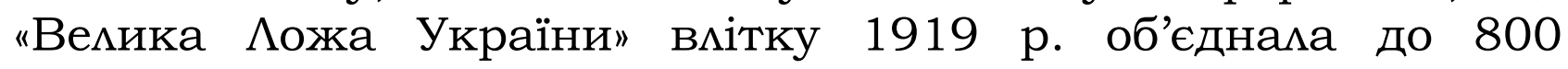


масонів, велика ціфра для переважно сільських теренів контрольованих армією УНР, скоріш за все до цієї кількості входили й масони, що залишилися на інших підконтрольних територіях (Одеси - під білогвардійською вмадою, Києва, Катеринослава, Полтави, Чернігова та Харківа - під владою більшовиків) [3]. Симпатиків С. Петлюри в Одесі 3 "масонських братів" навесні 1919 р. ми не знаємо, а можемо тільки припускати їхню наявлість, враховуючи, що Одеса до 1918 р. була значнім масонським центром (відомо, що серед одеських масонів було три професора-матиматика університету, можливо в Одесі існувала таємна університетська можа).

3 встановленням в Одесі білогвардійської влади генерала О. Гришина-Алмазова (який керував містом під контролем французького військового командування) контррозвідка заарештувала М. Слабченка, алк йому вдалося втекти й переховуватися на нелегальному становищі до опанування міста більшовиками. Нова влада більшовиків в Одесі (квітень-серпень 1919 р.) також репресувала М. Слабченка. Разом із боротьбистом М. Гордієвським М. Слабченко написав "Відкритий $и$ ме проти більшовицької політики у національному питанні. Михайло Єлисейович виступив проти радянської влади, звізавши свою долю з редакцією газети "Боротьба". 3 затвердженням в Одесі наприкінці серпня 1919 р. влади Збройних сим Півдня Росії армії А. Денікіна М. Слабченко перебував у підпіл^і на нелегальному становищі, був заарештуваний. Він продовжував працювати у підпільній газеті "Боротьба", агітував, як боротьбист у частинах УГА, що опинилися в Одесі у грудні 1919 р. 8 мютого 1920 р. Одеса знову була захопцена Червоною Армією, тоді утворився Одеський ревком, більшовики вели переговори з партіями борьбистів та боротьбистів щодо розподілу ділянок роботи в ньому.

Протягом ютого-березня 1920 р. представники партій боротьбистів - були представлені в місцевих ревкомах та радах. М. Слабченко працював в Одеському виборчому штабі боротьбистів, на вибори до Одеської ради робітничих депутатів, від працівників освіти, був надан список кандидатів в депутати, в якому з 12 чоловік, половина кандидатів була від борьбистів та боротьбістів. 20 березня 1920 р. Всеукраїнська 
конференція боротьбистів прийняла рішення про самоліквідацію партії, значна частина іiі чиенів влимась до КП(б)У. Разом із партією боротьбистів в одеську організацію КП(б)У увійшии місцеві мидери боротьбистів: А. Микалюк, А. КАочко та ін. В той же час М. Слабченко не пішов таким шляхом, залишаючись в компанії "незгодних 3 об'єднанням" боротьбистів [4].

Колишній бороьбист А. Микалюк був призначен завідувачем одеського віддіку народної освіти, став у 1921 р. організатором одеського "Тавариства української пролетарської культури". В цьому товаристві активно діяв М. Слабченко. Пізніше А. Микалюк керував процесом українізації в Одесі, чекісти вважали, що А. Микалюк на початку 1920-х рр. організував "боротьбистське підпіляя" в Одесі. Саме із А. Микалюком у М. Слабченка зав'язалися тісні ідеологічні стосунки, у це "боротьбістське підпімля" чекісти зарахували й М. Слабченка. Інший боротьбистський мідер А. КАочко у 1920-х рр. був ректором Одеського інституту народної освіти (ОІНО) в якому працював М. Слабченко. Ще 1918 р. А. Клочко вів українську соціалістичну пропаганду в гетьманській Одесі, брав участь у виданні газети «Вільне життя", товарищував з М. Слабченком [5, арк. 4-41].

B OIHO 31922 р. М. Слабченко першим став викладати навчальні предмети українською мовою, 31923 р. взяв активну участь в українізаційних процесах. У червні 1924 р. він написав заяву про відставку на знак протесту проти виключення студентів з ОІНО, як "чуждый советской власти эмемент". Подібний "демарш" міг закінчитися для М. Слабченка арештом, "парт'ячейка" вузу винесла рішення, що своїми діями М. Слабченко виступає проти "пролетаризації вищої школи" та "генеральної мінії партії». Тільки після того, як студентів поновици в ОІНО М. Слабченко забрав заяву, але від деканства відмовився.

Чекисти відносиоли М. Слабченка до "правої групи" українських науковців, оголосили вченого "анархістом" та "українським шовинистом", нарекали, що він товарищує 3 С. Єфремовим. У 1926 р. в апараті ДПУ України стало відомо про створення підпільного "контрреволюційного уряду України в Одесі». про те, що М. Слабченко тісно спілкується 3 
українськими єсерами, яки обіцяли йому "портфель міністра", після знищення більшовицької диктатури [6, с. 112, 577].

А. Клочко твердив на допитах в ДПУ: "боротьбистська організація офрормила контакти зі Слабченком та СВУ... Тоді ж ми спілкувалися 3 Слабченком і Чеховським... Я знаходячись, під особистим впливом спілкування зі Слабченком, долучився до українського націоналістичного руху" [5, арк. 23-34]. 31924 р., за інформацією ДПУ, почав створювати "кадри для боротьби з радянською владою серед студентів" - "боротьбистське підпіляя" в Одесі. Т. Віхрістюк у своїх свідченнях, звинувачував "одеську групу молодих українських націоналістів", до якої входив син Михайла Єлисейовича Тарас Слабченко, у "контрреволюції,, в проведенні таємних "націоналістичних вечірок", в "вихованні націоналістів", у зв'язках із Українською автокефальною церквою та селянськими повстанцями, що діяли під Одесою в 1921-1922 рр. (отаманами Радзієвським "Богуном" та Дорошенком "Запорожцем»). На допитах в ДПУ кунали свідчення, що у М. Слабченка "своя група", що він виступає за "дерусіфікацію",заявляючи про те, що "Україна повинна оринтуватися на Німеччину", що він "вважае, що кінець Радянської влади станиться у 1929 р.", бо "селяни підиймуться на місто", заявляє, що він "український імперіаліст"...[4, арк. 18,22,34, 50,52].

В 1919-1924 рр. в радянській Україні існувала законспірована антибільшовицька організація «Братство україської державності", що пов'язувала інтелігентські "українські кола" з українською політичною еміграцією. В 1929 р. чекісти вирішили, що "Спілка визволення України" було створено ще в 1925 р. 3 числа колишніх членів українських партій та "Братства української державності". Найбільш небезпечним вцаді здавалося проникнення “СВУ» в молодіжне середовище. М. Слабченко проходив у справі як ключова фрігура "одеського філіалу націоналістів СВУ". На допитах юноки, що звинувачувалися у причетності до "СВУ" не приховували свої погляди відкрито заявляючи, що вони $\epsilon$ прихильниками "незалежної радянської України" (колишне боротьбистське гасло), подібні свідчення дпв на допитах й М. Слабченко, що визнав відкриті чекістами "змочини" [8]. 
Треба сказати, що на допитах в ДПУ у 1922-1929 pp. фізичне катування було рідкосним явищем, а значна частина звинуваченних ДПУ у "контрреволюції", мала намір боротися, будя яким шияхом, проти більшовицької диктатури за здійснення справжної національної революції. Повністью відкідати всі зізнання політичних мідерів та суспільних діячив, що були дани на допитах у ДПУ 1920-х на поч. 1930-х рр. недоречно тому, що подібне заперечення, заперечують й будь-який спротив українського народу проти сталінського режиму. Чомусь звинувачення у селянському повстанстві часів колективізації сучасною українською історіографію визнається, а те, що С. Єфремов або М. Слабченко мріяли про знищення "диктатури пролетаріату" та відродження незалежної України - ні.

Політичні уподобання М. Слабченка в 1921-1929 pp. мало відомі, хоча за ним постійно пільнували агенти ЧКДПУ, залившивши для нас звіти про його "контрреволюційне обличча". Цілком імовірно, що М. Слабченко, став одним 3 мідерів одеської української "фронди", як А. КАичко та А. Микалюк, намагався використати процеси українізації та радянську систему освіти дия виховання нової української молоді, здатної до відродження ідей національної революції. В. М. Заруба писав, що М. Слабченко: «...робив усе можливе дмя майбутнього самостійного державного буття України, i все його життя - яскравий навчальний приклад жертовності в ім'я українського народу" [1, с. 396].

\section{Джерема та мітература:}

1.Заруба В. М. Історик держави i права України академік М. Є. Слабченко (1882-1952). - Дніпропетровськ, 2004. - 456 с.

2. Сериков А. И. Русское масонство 1731-2000. Энциклопедический словарь. М. Ю 2001.

3. Свитков Н. Масонство в русской эмиграции. - Париж, 1932; Савченко В. Україна масонська. - К., 2008. C. $282-290$.

4. Войтович А. Участь мівих політичних партій в діяльності місцевих органів влади на півдні України в 1920 році // Запискі історичного факультету. - Одеса, 1996. - Вип. 2. C. 90-92.

5. Архів УСБУ в Одеський області. ФП. Спр. 10349-п. 
6. Українська інтелігенція і влада. Зведення секретного віддіку ДПУ УСРР 1927-1929 рр. Упор. В. Данименко. Київ: Темпора, 2012

7. Архів УСБУ в Одеський області. ФП. Спр. 10203-п.

8. Семенко Ю. Наталья Павлушкова. - К., 1999.

\section{References}

1. Zaruba V. M. Istoryk derzhavy i prava Ukrainy akademik M. Ye. Slabchenko (1882-1952). - Dnipropetrovsk, 2004. - 456 s. 2. Serykov A. Y. Russkoe masonstvo 1731-2000. Entsyklopedycheskyi slovar. M.Yu 2001.

3. Svytkov N. Masonstvo v russkoi эmyhratsyy. - Paryzh, 1932; Savchenko V. Ukraina masonska. - K., 2008. - S. 282-290.

4. Voitovych A. Uchast livykh politychnykh partii $v$ diialnosti mistsevykh orhaniv vlady na pivdni Ukrainy v 1920 rotsi // Zapyski istorychnoho fakultetu. - Odesa, 1996. Vyp. 2. s. 90-92.

5. Arkhiv USBU v Odeskyi oblasti. FP. Spr. 10349-p.

6. Ukrainska intelihentsiia i vlada. Zvedennia sekretnoho viddilu DPU USRR 1927-1929 rr. Upor. V. Danylenko. Kyiv: Tempora, 2012

7. Arkhiv USBU v Odeskyi oblasti. FP. Spr. 10203-p.

8. Semenko Yu. Natalia Pavlushkova. - K., 1999.

Виктор Савченко

\section{ПОАИТИЧЕСКИЕ ПРЕДПОЧТЕНИЯ ПРОФЕССОРА} М. СААБЧЕHКО

В статье рассматривается эволюиия политических взглядов профрессора $M$. Слабченко под воздействием глобальных изменений (1905-1929 г2.). Автор призывает $к$ дискуссии и высказывает предположение о том, ито М. Слабченко был масоном или человеком "масонского круга", что его участие $к$ украинских соииалистических партиях, $в$ боротьбистском подполье не закончилось в 1920 г. Для М. Слабченко 1920-е годы стали годами продолжения политической борьбы за украинскую идеб и украинскую независимость.

Ключевые слова: революиия, боротьбисты, масонство, подполья, украинизаиия, ГПУ. 


\section{POLITICAL PREFERENCES OF PROFESSOR M. SLABCHENKO}

The article examines the evolution of political views of professor $M$. Slabchenko under the influence of global changes (1905-1929). The author calls for discussion and suggests that $M$. Slabchenko was a freemason or a man of the "masonic circle", that his participation in the ukrainian socialist parties in the borotbist underground did not end in 1920. For M. Slabchenko, the 1920-s became years continuation of the political struggle for the ukrainian idea and ukrainian independence.

Key words: revolution, wrestling, freemasonry, underground, ukrainization, DPU.

Отримано: 12.12.2017

УДК 94(71=161.2)

\section{Анатолій Бодруг}

\section{ФЕНОМЕН КОЗАЦТВА \\ ЯК НАЦІСЗБЕРІГАЮЧИЙ ЧИННИК КУАЬТУРИ УКРАЇНСЫКОї ДІАСПОРИ КАНАДИ \\ (середина XX - початок XXI ст.)}

Мета даної наукової статті полягае в визначенні шляхів збереження наиіональної пам'яті представниками української діаспори Канади на основі славного козаиького минулого. Для досягнення зазначеної мети було залучено необхідну кількість джерел та історіографрічної літератури, які торкались різних аспектів порушеної проблеми. Автором було використано такі наукові методи дослідження, як історико-генетичний та історико-порівняльний. $B$ межках даної статті було розглянуто діяльність культурних та наукових організаиій пов'язаних з козаиьким напрямом. Автор досліджуе вплив козацької культури на розвиток украӥнсъкої спільноти Канади. Окрема увага присвячена українським фестивалям 